\title{
Herne on vaativa suorakylvettävä
}

\author{
Hannu Känkänen ${ }^{1)}$, Erja Huusela-Veistola ${ }^{1)}$, Heikki Jalli ${ }^{1)}$, Marja Jalli ${ }^{1)}$ \\ ${ }^{1)}$ MTT Kasvintuotannon tutkimus, 31600 Jokioinen, etunimi.sukunimi@mtt.fi
}

\section{Tiivistelmä}

Suorakylväjä tarvitsee vaihtoehtoja kasvivalikoimaansa muun muassa pellon pintaan jäävän olkimäärän hallitsemiseksi ja kasvitautien hillitsemiseksi. Ilmakehän typpeä sitova herne on viljaa vähäisemmän ja nopeasti hajoavan puintitähteensä ansiosta erinomainen lisä myös muokkaamattoman maan kiertoon. Toisaalta herne on viljoja vaativampi suorakylvettävä. Kylvötiheyttä on lisättävä muokattuun maahan verrattuna saman kasvutiheyden saavuttamiseksi, vaikka kallis siemen ei siihen houkuta. Hyvänkin taimettumisen jälkeen herne kärsii herkästi alkukesän sateista, jos maan kuohkeus tai vettä johtavien huokosten määrä ei riitä. Maan kasvukuntoon onkin kiinnitettävä erityistä huomiota herneen suorakylvöä harkittaessa. Parhaimmillaan herneestä saadaan hyviä satoja muokkaamattomassa maassa.

Jokioisten savimailla on kuuden vuoden ajan tehty kokeita, joissa herneen suorakylvöä on verrattu muokatun maan kylvöön. Vuosina 2005 - 2008 tutkittiin herneen ja neljän muun kasvin suorakylvöä kevätvehnän esikasveina. Vuonna 2010 herneen kasvua verrattiin muokatuissa ja kahdeksatta vuotta suorakylvetyssä maassa. Vuodesta 2005 lähtien herne on ollut mukana muokatun ja muokkaamattoman maan viljelykiertokokeissa.

Sää on usein ratkaiseva tekijä, kun muokatun ja muokkaamattoman maan keskinäinen ero sadon määrän suhteen kasvukausien välillä vaihtelee. Herne reagoi ohraakin voimakkaammin säihin, sitä suorastaan voi pitää mittarina pellon alttiudelle ongelmiin suorakylvösysteemissä. Jos kylvöajasta on selvitty kunnialla, on alkukesän sateisuus eniten ongelmia aiheuttava tekijä suorakylvetylle kasville. Sateita seuraavat pitkät hellekaudet täydentävät stressin. Kyseisissä oloissa vuonna 2010 muokkausmenetelmän vaikutus näkyi erityisen voimakkaasti herkän herneen kasvussa. Muokkaamattoman maan herne oli kokeessamme melko harvaa ja erittäin lyhyttä eikä kasviyksilöä kohti ollut kuin yksi tai kaksi pientä palkoa. Siemensadon määrä oli $570 \mathrm{~kg} / \mathrm{ha}$. Parhaiten herne menestyi syyskynnetyssä maassa, jossa siemensadon määrä oli $2580 \mathrm{~kg} / \mathrm{ha}$. Syksyllä kultivoidun maan siemensato oli $2150 \mathrm{~kg} / \mathrm{ha}$.

Vuodet 2005 - 2007 olivat suorakylvölle edullisia kuivan alku- ja keskikesän ansiosta. Viljojen jyväsadot olivat suorakylvössä muokattua maata suuremmat. Herneen siemensato oli silti suurempi kynnetyssä (keskimäärin $3270 \mathrm{~kg} / \mathrm{ha}$ ) kuin muokkaamattomassa $(2720 \mathrm{~kg} / \mathrm{ha})$ maassa. Parhaimmillaan, vuonna 2005, hernesato oli täsmälleen sama $(3580 \mathrm{~kg} / \mathrm{ha})$ molemmilla menetelmillä.

Herne tuo biologisen typensidonnan kautta typpeä myös seuraavan kasvin käyttöön. Maahan muokkaaminen tehostaa yleensä kasvimassan typen vapautumista. Vaikka tuleentuneen herneen varsien typpipitoisuus onkin melko alhainen, näyttää siltä, että suorakylvö vähentää tai ainakin hidastaa herneen jäännöstypen siirtymistä seuraavaan kasviin. Kylvettäessä kevätvehnää vuosina 2006 - 2008 , typpilannoitusta vähennettiin $30 \mathrm{~kg} / \mathrm{ha}$ herneen jälkeen. Kynnetyssä maassa kevätvehnän jyväsato oli herneen jälkeen $60 \mathrm{~kg} / \mathrm{ha} \mathrm{korkeampi} \mathrm{kuin} \mathrm{kaikkien} \mathrm{esikasvien} \mathrm{jälkeen} \mathrm{keskimäärin,} \mathrm{mutta} \mathrm{suorakylvös-}$ sä $310 \mathrm{~kg} / \mathrm{ha}$ pienempi. Osittain tämä selittyy edeltävän herneen biomassan määrän kautta, mutta myös typen siirtymisen tehokkuus olisi lisätutkimisen arvoista.

\section{Asiasanat}

Herne, valkuaiskasvit, palkokasvit, muokkaus, kylvö, kyntö, kevytmuokkaus, suorakylvö 


\section{Hernettä tarvitaan kiertoon, suorakylvössäkin}

Muokkaamatta jättäminen on yleinen ja vakiintunut käytäntö suomalaisilla pelloilla. Tuoreen maatalouden rakennetutkimuksen eli maatalouslaskennan mukaan $17 \%$ viljanviljelytilojen pinta-alasta oli viime vuonna suorakylvettyä (Anon 2011). Yksipuolinen, lähinnä kevätviljoihin painottuva viljely on yleistä etenkin eteläisessä Suomessa. Yksipuolisuutta kuvaa maatalouslaskennan tulos, jonka mukaan viidenneksellä peltomaasta viljeltiin viimeisen kolmen vuoden ajan samaa kasvilajia. Samojen kasvilajien toistuvuus koskee nimenomaan viljatiloilla yleisesti viljeltäviä kasveja, sillä edellä olevassa ei ole mukana alaa, jolla viljeltiin pysyvää nurmea.

Viljelykierron merkitys korostuu muokkaamattomassa maassa muun muassa kasvitautien hillitsemisen (Duczek ym. 1999) ja rikkakasvien torjunnan (Liebmah \& Dyck 1993) kannalta. Tuhoeläinten hallinnassa lohkokohtainen viljelykierto ei aina riitä vaan tarvitaan laajempaa alueellista viljelykiertoa (Huusela-Veistola \& Jauhiainen 2006). Lisäksi suorakylväjä tarvitsee vaihtoehtoja kasvivalikoimaansa muun muassa pellon pintaan jäävän olkimäärän hallitsemiseksi. Herne on viljaa vähäisemmän ja nopeammin hajoavan puintitähteensä ansiosta erinomainen lisä muokkaamattoman maan kiertoon.

Ilmakehän typpeä sitovana palkokasvina herne voi korvata synteettistä typpilannoitusta niin viljelyvuonna kuin seuraavana kesänä. Lindénin (2008) mukaan tuleentuneena korjatun rehuherneen jälkeen typpilannoitusta voidaan vähentää $20-30 \mathrm{~kg} \mathrm{ha}^{-1}$. Toisaalta Lindén (2008) huomauttaa, että usein herneen aikaansaama sadonlisäys viljan monokulttuuriin verrattuna johtuu enemmän herneen ns. maata puhdistavasta vaikutuksesta kuin typpivasteesta. Kirkegaardin ym. (2008) review -artikkelissa viitataan kahdenlaisiin tuloksiin: Toisissa tutkimuksissa herneen satoa lisäävä vaikutus on perustunut lähinnä seuraavan kasvin lisääntyneeseen typen saantiin, toisissa satohyöty on johtunut lähes yksinomaan muista tekijöistä. He toteavatkin, että typpihyödyn ja muiden esikasvihyötyjen suhteellinen osuus vaihtelee monista maahan ja säähän liittyvistä tekijöistä johtuen. Joka tapauksessa viljelykierron monipuolistaminen palkokasvien avulla näyttäisi olevan paikallaan, myös suorakylvössä.

Kasvimassan maahan muokkaaminen nopeuttaa sen hajoamista. Se, että suorakylvössä muokkausta ei tehdä, voikin heikentää herneen typpivastetta seuraavalle kasville. Typpivaikutuksen toteumaan kytkeytyy lisäksi se, että typen vapautuminen maasta hidastuu, kun maan muokkaaminen vähenee (Kristensen et al. 2000).

Herneen ottamista mukaan suorakylvön viljelykiertoon voi hidastaa se, että kylvö on perinteisesti suositeltu tekemään kuohkeaksi muokattuun mahan. Vaikka peltokohtaiset ja lohkon viljelyhistoriaan liittyvät erot aiheuttavat oleellisia eroja kasvualustassa, ei muokkaamattomassa savimaassa useinkaan päästä herneelle optimaalisiin oloihin taimettumisen kannalta. MTT:n suorakylvökokeissa viljojen siemenmäärää on pitänyt lisätä, jotta suorakylvössä päästäisiin tavanomaisiin kasvutiheyksiin (Känkänen ym. 2011), mutta herneen siemenen lisäystarve näyttää viljojakin suuremmalta. Taimettuminen voi jäädä jopa puoleen muokatun maan taimettumisesta ja hyvissäkin oloissa on tarvittu viidenneksen siemenmäärän lisäys samaan taimimäärään pääsemiseksi (Känkänen 2008). Vaikka kalliin siemenen lisääminen ei houkuta, on riittävän kasvitiheyden saavuttaminen herneellä erityisen tärkeää määrältään ja laadultaan hyvän sadon saavuttamiseksi (Känkänen ja Kontturi 1988).

Muokkaamattomassa maassa on kynnettyä vähemmän tilavuutta ottaa vastaan suuria sademääriä. Tämä lisää märkyydelle aran herneen viljelyriskiä kynnettyyn maahan verrattuna. Hyvänkin taimettumisen jälkeen herne kärsii herkästi alkukesän sateista, jos maan kuohkeus tai vettä johtavien huokosten määrä ei riitä.

Tässä artikkelissa tarkastellaan eri kokeissa saatuja kokemuksia suorakylvön vaikutuksista herneen satoon. Herneen menestymistä peilataan 2000-luvun aikana kertyneeseen kokemukseen suorakylvölle edullisten ja haitallisten sääolojen esiintymisestä. Herneen esikasvivaikutusta tarkastellaan tässä vaiheessa yhden, kolmena vuonna toistetun, kenttäkokeen pohjalta.

\section{Herneen suorakylvöä kolmessa kokeessa}

MTT:n Jokioisten pelloilla on tehty suorakylvökokeita yli kymmenen vuoden ajan. Kuutena viimeisimpänä vuonna herne on kuulunut suorakylvökokeiden tutkittaviin kasveihin. Suorakylvöön käytettiin VM suorakylvökonetta, muokattu maa oli pääsääntöisesti syksyllä kynnettyä. Kynnös tasausäestettiin keväällä ja kylvettiin tavanomaisella kylvölannoittimella joko S-piikkiäestyksen jälkeen tai jyrsinkylvönä. Kynnöksen tasaaminen auttoi jossain määrin eri kylvötapojen ajoittumista lähelle toisiaan, mutta kylvöt pyrittiin aina tekemään maan kylvettävyyden kannalta parhaaseen mahdolliseen aikaan. 
Useimmiten eri menetelmien kylvöt päästiin tekemään samana tai lähes saman päivänä. Yksittäisissä tapauksissa kylvöajan sateet siirsivät suorakylvöä myöhäisemmäksi, enimmillään kaksi viikkoa.

Vuosina 2005 - 2008 toteutettiin koe "Monipuolisuutta suorakylvön viljelykiertoon: kevätkylvöiset yksivuotiset kasvit" (koe 1). Tavoitteena oli selvittää erilaisten kasvien suorakylvön onnistuminen, samalla verraten kasvua muokatun maan kylvöön. Esikasvivaikutusta mitattiin seuraavana keväänä kylvetyn vehnän avulla. Herneen (lajike Hulda) lisäksi tutkittavia kasveja olivat monitahoinen ohra (Voitto), kaura (Roope), kevätrypsi (Hohto) ja kitupellava eli ruistankio eli camelina (ei lajikenimeä). Peltolohko, jolla kokeet toteutettiin, oli ollut vuodesta 2001 asti suorakylvössä. Siirtymävaiheena yleisesti pidetty viiden vuoden aika oli siten juuri täyttymässä tai täyttynyt. Koealueet olivat hiuesavea, sijainnista riippuen vähämultaista tai multavaa.

MoniPalko -hankkeessa herne ja suorakylvö ovat olleet osallisina kahdessa kokeessa. Vuosina 2005 - 2011 herne on ollut mukana muokatun ja muokkaamattoman maan viljelykiertokokeessa (koe 2). Tavoitteena oli selvittää viljelykierron mahdollisuuksia vehnän kasvintuhoojien esiintymisen hillitsijänä. Herne (lajike Hulda) oli kevätvehnän esikasvina kierrossa, jossa vehnää kylvettiin joka neljäs vuosi. Hernettä edelsivät viljelykierrossa rypsi ja ohra. Viljelykiertokoe toteutettiin sekä muokatussa että muokkaamattomassa ympäristössä. Koealue oli multavaa aitosavea.

Muokkausintensiteettikokeessa vuonna 2010 herneen kasvua verrattiin muokkaamattomassa ja kolmella tavalla muokatussa maassa (koe 3). Suorakylvön lisäksi koejäseninä olivat syyskyntö, kultivointi syksyllä ja sängen jyrsintä keväällä juuri ennen kylvöä. Esikasvina oli kevätrypsi. Suorakylvetty alue oli kahdeksatta vuotta muokkaamaton, ja myös keväällä jyrsitty alue oli ollut seitsemän edellistä vuotta ilman muokkausta. Koealue oli vähämultaista hiuesavea.

\section{Herkkyys sääoloille korostuu suorakylvössä}

Jo viljoilla tehdyissä suorakylvökokeissa on käynyt ilmi, että suorakylvön ja kynnetyn maan välinen paremmuus vaihtelee vuosittain, ja vaihtelu on vahvasti kytköksissä säähän (Känkänen ym. 2011). Kevätviljoista herkimmin sääoloihin reagoi ohra, mutta etenkin kesän 2010 kokemusten pohjalta herne on ohraakin herkempi, ja sitä voi pitää suorastaan mittarina pellon alttiudelle ongelmiin suorakylvösysteemissä.

Useista kasveista eri kokeissa saatujen kokemusten perusteella kesät voidaan jakaa ns. hyviin ja huonoihin suorakylvövuosiin. Jako perustuu ennen kaikkea suorakylvön vertaamiseen muokatun maan kasvun ja sadon kanssa, ei välttämättä sadon määrän vertailuun vuosien välillä. Hyville vuosille tyypillistä ovat vähäiset sateet keväällä ja alkukesällä sekä kynnetyn maan kannalta liian vähäinen sademäärä myöhemminkin kesällä. Muokkaamattoman maan vähäisen haihdutuksen ansiosta vettä on kasvien käytettävissä paremmin ja pidempään. Suorakylvölle huonoja vuosia leimaavat alku- tai keskikesän runsaat sateet. Sateita seuraavat pitkät hellekaudet täydentävät stressin.

2000-luvulla suorakylvön kannalta sääoloiltaan huonoja vuosia ovat olleet vuodet 2001, 2003, 2004, 2010 ja 2011. Hyviä suorakylvökesiä ovat olleet vuodet 2002, 2005, 2006, 2007 ja 2008. Ainoastaan vuotta 2009, jolloin alku- tai keskikesä ei ollut Jokioisilla erityisen märkä tai kuiva, ei voida luokitella kumpaankaan ryhmään. Myöskään pitkiä hellekausia ei kesällä 2009 ollut. Hernekokeiden osalle on siis kertynyt neljä ns. hyvää ja kaksi huonoa suorakylvökesää sekä yksi neutraali kesä.

Kokeen 1 kaikki esikasvivuodet 2005 - 2007 sekä viimeinenkin kevätvehnän vuosi 2008 olivat suorakylvölle edullisia kuivan alku- ja keskikesän ansiosta. Tämä näkyi myös kokeen viljojen jyväsadoissa, jotka olivat suorakylvössä muokattua maata suuremmat. Sen sijaan herneen siemensato oli suurempi kynnetyssä (keskimäärin $3270 \mathrm{~kg} / \mathrm{ha}$ ) kuin muokkaamattomassa $(2720 \mathrm{~kg} / \mathrm{ha}$ ) maassa (kuva 1). Parhaimmillaan, vuonna 2005 , hernesato oli täsmälleen sama $(3580 \mathrm{~kg} / \mathrm{ha})$ molemmilla menetelmillä. 


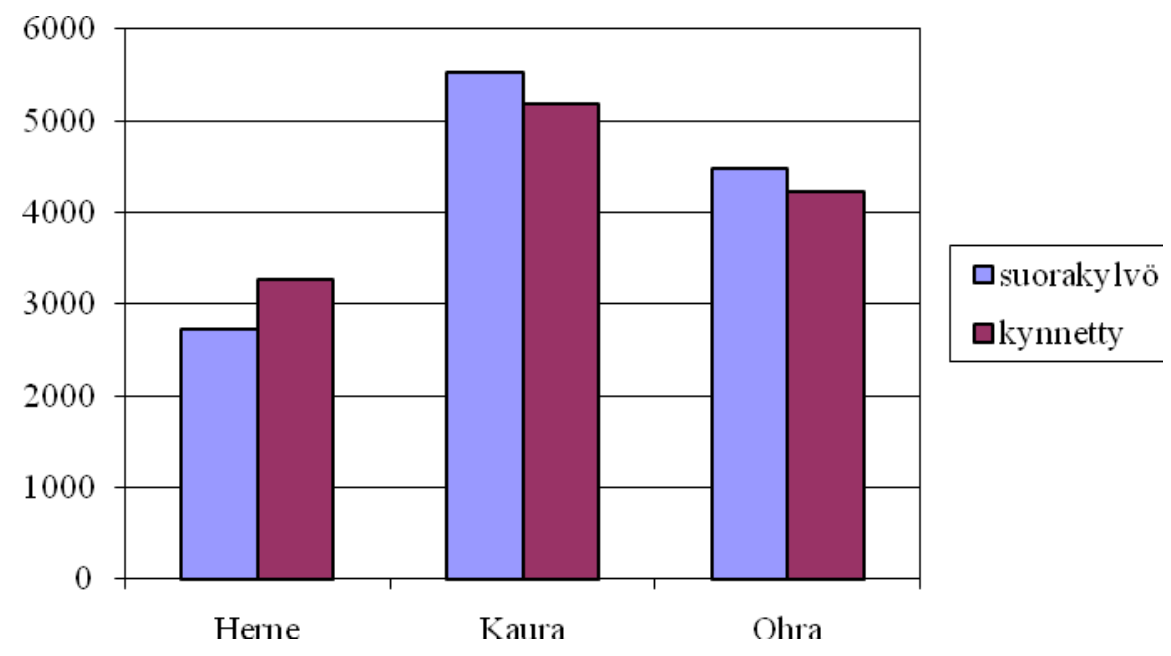

Kuva 1: Herneen siemensato sekä kauran ja ohran jyväsato $\left(\mathrm{kg} \mathrm{ha}^{-1}\right)$ suorakylvetyssä ja kynnetyssä maassa keskimäärin vuosina 2005 - 2007 Jokioisten esikasvikokeessa (koe 1).

Vuosi 2005 toisaalta osoitti, että herne voi parhaimmillaan kasvaa muokkaamattomassa maassa vahvemmin kuin muokatussa. Suorakylvetyn herneen kasvitiheys jäi nimittäin puoleen kynnetyn maan tiheydestä. Yhtä suuri siemensato saavutettiin sen ansiosta, että suorakylvettyihin kasviyksilöihin kehittyi enemmän palkoja ja palkoihin enemmän siemeniä (Känkänen 2008). Seuraavanakin kesänä suorakylvetty herne jäi harvemmaksi, mutta lisääntyneen kasvutilan hyödyntäminen suurempina satokomponenttien arvoina ei nostanut satoa tavanomaisesti kylvetyn herneen tasolle. Sen sijaan vaikka vuonna 2007 suorakylvö ylsi viidenneksellä lisätyn siemenmäärän ansiosta samaan taimitiheyteen kuin muokatun maan herne, jäi siemensato $900 \mathrm{~kg} \mathrm{ha}^{-1}$ pienemmäksi kuin muokatussa maassa. Tällä kertaa syynä oli se, että kynnetty maa pystyi hyödyntämään heinäkuun lopun runsaat sateet ja sitä seuranneet helteet. Se näkyi pidempään jatkuneena kasvuna ja palkojen muodostuksena kuin muokkaamattomassa maassa (Känkänen 2008).

Vuoden 2010 oloissa muokkausmenetelmän vaikutus näkyi erityisen voimakkaasti herneen kasvussa (kokeet 2 ja 3). Alkukesän runsaat sateet ja niitä seuranneet helteet merkitsivät heikohkoa satoa myös muokatussa maassa, mutta muokkaamattomuus korosti ongelmia. Suorakylvetty herne oli melko harvaa ja erittäin lyhyttä eikä kasviyksilöä kohti ollut kuin yksi tai kaksi pientä palkoa. Kokeen 3 siemensadon määrä suorakylvössä oli $570 \mathrm{~kg} \mathrm{ha}^{-1}$. Keväällä sänkimaan jyrsinnän jälkeen kylvetty herne tuotti hieman paremmin, $1030 \mathrm{~kg} \mathrm{ha}^{-1}$. Syksyllä kultivoidun maan siemensato oli $2150 \mathrm{~kg} \mathrm{ha}^{-1}$. Parhaiten herne menestyi syyskynnetyssä maassa, jossa siemensadon määrä oli $2580 \mathrm{~kg} \mathrm{ha}^{-1}$. Viljelykiertokokeen (koe 2) muokatut ruudut tuottivat siemensatoa vain $1220 \mathrm{~kg} \mathrm{ha}^{-1}$, mutta muokkaamattomat vielä vähemmän eli keskimäärin $790 \mathrm{~kg} \mathrm{ha}^{-1}$.

Tarkasteltaessa kaikkia Jokioisista käytettävissä olevia tapauksia, on suorakylvöllä päästy ns. hyvinä suorakylvövuosina lähelle muokatun maan satoja. Suorakylvön keskisato on ollut $2800 \mathrm{~kg} \mathrm{ha}^{-1}$, muokatun maan $3040 \mathrm{~kg} \mathrm{ha}^{-1}$ (6 tapausta). Sääoloiltaan erityisesti suorakylvön kannalta huonoina vuosina suorakylvön keskisato on ollut vain $650 \mathrm{~kg} \mathrm{ha}^{-1}$, kun kynnetyistä maista on saatu keskimäärin 1860 kilon hehtaarisato (3 tapausta). Ainoana ns. neutraalina kesänä siemensato oli $440 \mathrm{~kg} \mathrm{ha}^{-1}$ pienempi suorakylvettynä kuin muokatussa maassa (1 tapaus).

\section{Typen siirtyminen voi hankaloitua}

Herneen viljely vähentää synteettisen typen tarvetta niin varsinaisena herneen viljelyvuonna kuin seuraavanakin kesänä. Biologinen typensidonta toimi parhaiten ilmavassa ja sopivan kosteassa maassa, mikä osaltaan selittää herneen herkkää reagointia sääoloihin, jos muokkaamattoman maan rakenne ei ole hyvässä kunnossa. Kynnöllä saadaan aikaan lisää ilmavuutta suhteellisen heikkorakenteisissakin maissa.

Muokkaamattomuus voi muuttaa oleellisesti myös hernekasvuston sisältämän typen vapautu-mista ja etenkin kasvustotähteiden sisältämän typen liukenemista maahan. Maahan muokkaaminen 
tehostaa yleensä kasvimassan typen vapautumista (Kristensen ym. 2000). Lindénin (2008) mukaan tuleentuneen herneen maanpäällisen massan merkitys typen lähteenä on kuitenkin vähäinen, koska sen typpipitoisuus on suhteellisen alhainen. Meidän tuloksemme tukevat tätä, sillä muun maanpäällisen biomassan kuin siementen typpipitoisuus jäi lähelle yhtä prosenttia. Suoraan typpilannoitusvaikutukseen katsotaan yleensä tarvittavan vähintään 1,5\% typpipitoisuutta. Toisaalta herneen puintitähteiden typpipitoisuus on kuitenkin selvästi viljan olkien typpipitoisuutta korkeampi, joten muokkaamattomuus heikentää teoriassa herneen suhteellista edullisuutta viljoihin nähden.

Kokeessa 1 verrattiin esikasvivaikutuksia seuraavan kevätvehnän sadon perusteella. Kevätvehnän typpilannoitusta vähennettiin $30 \mathrm{~kg} \mathrm{ha}^{-1}$ herneen jälkeen. Kynnetyssä maassa herne kuului esikasvina keskikastiin alennetusta typpilannoituksesta huolimatta, ja kevätvehnän jyväsato oli herneen jälkeen $60 \mathrm{~kg} \mathrm{ha}^{-1}$ korkeampi kuin kaikkien esikasvien jälkeen keskimäärin. Sen sijaan suorakylvetyssä maassa herne esikasvina ei korvannut 30 kilon typpilannoituksen alenemista, vaan sato jäi herneen jälkeen kaikkein pienimmäksi ja $310 \mathrm{~kg} \mathrm{ha}^{-1}$ pienemmäksi kuin muiden esikasvien jälkeen keskimäärin (kuva 2).

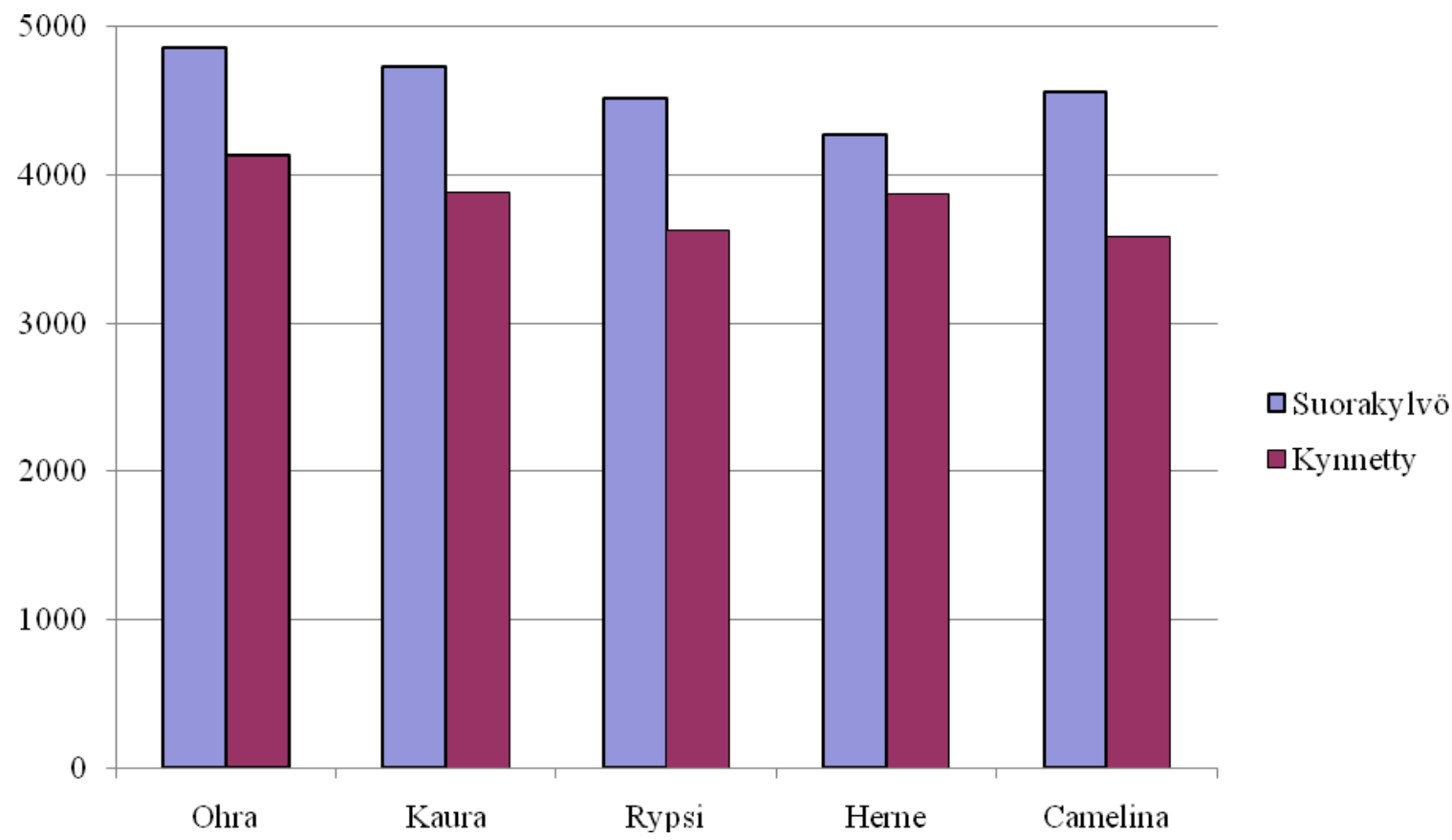

Kuva 2: Kevätvehnän jyväsato $\left(\mathrm{kg} \mathrm{ha}^{-1}\right)$ keskimäärin vuosina 2006 - 2008 eri esikasvien jälkeen suorakylvettynä ja kynnettyyn maahan kylvettynä.

Suorakylvön myötä heikentynyt herneen esikasvivaikutus ei kuitenkaan suoraan kerro herneen typen huonommasta siirtymisestä muokkaamattomassa maassa, sillä myös herneen biomassa oli pienempi suorakylvössä. Olisikin tärkeää päästä vertaamaan tasavertaisten hernekasvustojen jälkeen herneen typen vapautumista ja siirtymistä seuraavalle kasville eri muokkausmenetelmissä. Tähän itse asiassa jo pyrittiinkin muokkausintensiteettikokeessa (koe 3), mutta lähes täydellinen suorakylvetyn herneen kato vesitti suunnitelmat.

Muokkaamattomassa ympäristössä voivat herneen kasvitautiongelmat tulla esiin voimakkaammin kuin muokatussa ympäristössä. Useat maa- ja kasvijätelevintäiset taudinaiheuttajat vioittavat erityisesti kasvin juuristoa sekä tyviä ja heikentävät herneen kasvukuntoa (Kraft \& Pfleger 2001). Viljelykiertokokeessa (2010 - 2011) oli herneen tyvien vioitusta kuvaava tyvitauti-indeksi (0 - 100) korrenkasvun alussa muokatun maan tyvissä 17 ja muokkaamattoman maan tyvissä 25 . Kasvitautien vuoksi suositellaan viljelykiertoa, jossa herne kasvaa vain joka viides vuosi.

Suorakylvön vaikutukset tuhoeläinmääriin ovat olleet vaihtelevia (Stinner \& House 1990). Suorakylvön on muualla havaittu vähentävän juovahernekärsäkkään vioituksia herneellä (Hanavan et al. 2008), mutta Jokioisten suorakylvökokeissa ei selvää eroa kylvötapojen välillä havaittu. 
Tulevaisuudessa pitäisi entistä selkeämmin keskittyä kehittämään herneen suorakylvöön liittyviä menetelmiä, sen sijaan että vertaillaan muokkausta ja muokkaamattomuutta toisiinsa. Joka tapauksessa voidaan todeta, että maan kasvukuntoon on kiinnitettävä erityistä huomiota herneen suorakylvöä harkittaessa. Parhaimmillaan herneestä saadaan hyviä satoja myös muokkaamattomassa maassa.

\section{Kirjallisuus}

Anon 2011 SVT: Tike, Maatalouden rakennetutkimus, Maatalouslaskenta 2010.

Duczek, L.J., Sutherland, K.A., Reed, S.L., Bailey, K.L. \& Lafond, G.P. 1999. Survival of leaf spot pathogens on crop residues of wheat and barley in Saskatchewan. Canadian Journal of Plant Pathology 21: 165-173.

Hanan, R.P., Bosque-Perez, N.A., Scohtzko, D.J. \& Eigenbrode, S.D. 2010. Influence of tillage on adult and immature pea leaf weevil (Coleoptera: Curculionidae) densities in pea. Field and Forage Crops 103: 691-697.

Huusela-Veistola, E., \& Jauhainen, L. 2006. Expansion of pea cropping increases the risk of pea moth (Cydia nigricana; Lep., Tortricidae) infestation. Journal of Applied Entomology, 130, 142-149.

Kirkegaard, J., Christen, O., Krupinsky, J. \& Layzell, D. 2008. Break crop benefits in temperate wheat production.Field Crops Research 107:185-195.

Kristensen, H.L., McCarty, G.W. \& Meisinger, J.J. 2000. Effects of soil structure disturbance on mineralization of organic soil nitrogen. Soil Science Society of America Journal 64: 371-378.

Kraft, J.M. \& Pfleger, F.L. 2001. Compendium of Pea Diseases and Pests. American Phytopathological Society, second edition. St. Paul, Minnesota USA, 67 p.

Känkänen, H. 2008. Herne reagoi kylvötapaan. Maaseudun Tiede 65, 1(10.3.2008): 6.

Känkänen, H. \& Kontturi, M. 1988. Kylvötiheyden vaikutus lehtityypiltään erilaisten herneiden sadon muodostumiseen. Maatalouden tutkimuskeskus. Tiedote 22/88: $69 \mathrm{p}$.

Känkänen, H., Alakukku, L., Salo, Y. \& Pitkänen, T. 2011. Growth and yield of spring cereals during transition to zero tillage on clay soils. European journal of agronomy 34: 35-45.

Liebman, M. \& Dyck, E. 1993. Crop Rotation and Intercropping Strategies for Weed Management. Ecological Applications 3:92-122Kirkegaard, J., Christen, O., Krupinsky, J., Layzell, D. 2008. Break crop benefits in temperate wheat production. Field Crops Research 107: 185-195

Lindén, B. 2008. Efterverkan av olika förfrukter: inverkan på stråsädesgrödors avkastning och kvävetillgång en litteraturöversikt. Avdelningen för precisionsodling Rapport 14 Skara 2008.

Stinner, B.R. \& House, G.J. 1990. Arthropods and other invertebrates in conservation tillage agriculture. Annual Review of Entomology 35: 299-318. 